\title{
New plastic formations in the Anthropocene.
}

\author{
De-la-Torre, Gabriel Enrique, Dioses-Salinas, Diana Carolina, \\ Pizarro-Ortega, Carlos Ivan y Santillán, Luis.
}

Cita:

De-la-Torre, Gabriel Enrique, Dioses-Salinas, Diana Carolina, PizarroOrtega, Carlos Ivan y Santillán, Luis (2021). New plastic formations in the Anthropocene. Science of The Total Environment, 754, 14221-6.

Dirección estable: https://www.aacademica.org/gabriel.e.delatorre/7 ARK: https://n2t.net/ark:/13683/podQ/mon

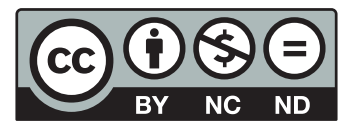


Review

\title{
New plastic formations in the Anthropocene
}

\author{
Gabriel Enrique De-la-Torre ${ }^{\mathrm{a}, *}$, Diana Carolina Dioses-Salinas a \\ Carlos Ivan Pizarro-Ortega a , Luis Santillán ${ }^{\text {a,b }}$ \\ a Universidad San Ignacio de Loyola, Av. La Fontana 501, Lima 12, Peru \\ b Peruvian Centre for Cetacean Research (CEPEC), Pucusana, Peru
}

\section{H I G H L I G H T S}

- New plastic-associated contaminants have been recently reported in literature.

- The fate and effects depend on the characteristics of each new contaminant.

- Plastic pollution monitoring guidelines must include the new terminology.

- Further research is needed regarding the suspected impacts of these contaminants.

\section{A R T I C L E I N F O}

\section{Article history:}

Received 28 July 2020

Received in revised form 22 August 2020

Accepted 3 September 2020

Available online $\mathrm{xxxx}$

Editor: Damia Barcelo

\section{Keywords:}

Anthropogenic

Pollution

Plasticene

Peru

Conglomerate

Plastic rock

\section{GRAPHICALA B STRACT}

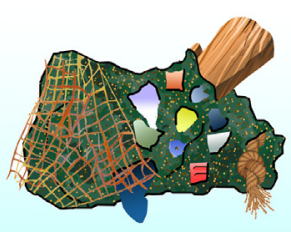

Plastiglomerates

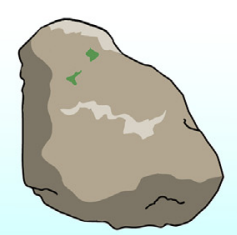

Pyroplastics

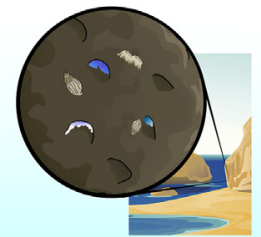

Plasticrusts

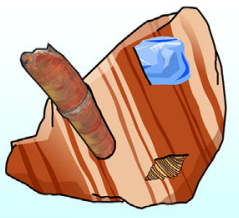

Anthropoquinas

\begin{abstract}
A B S T R A C T
Plastic pollution is one of the major challenges in the Anthropocene. Upon reaching the marine environment, plastic debris is subject to anthropogenic and environmental conditions that result in novel items that vary in composition, physical and chemical characteristics. Here, we reviewed and discussed the potential fate and threat to the environment of four recently described plastic formations: Plastiglomerates, pyroplastics, plasticrusts, and anthropoquinas. The threats identified were mostly related to the release of toxic chemicals and plastic ingestion. Transportation of alien invasive species or microbial pathogens and fragmentation of larger plastics into microplastics $(<5 \mathrm{~mm})$, potentially reaching marine trophic webs, are suspected as potential impacts based on the characteristics of these plastic formations. Some plastic forms may persist in the environment and voyage across the ocean, while others are denser and less likely to enter the plastic cycle or interact with biota. In the latter case, plastics are expected to become buried in the sediment and incorporate into the geological record. It is necessary to establish sampling protocols or standards that are specific to each plastic formation and start reporting the occurrence of these new plastic categories as such to avoid underestimating plastic pollution in marine environments. It is suggested that monitoring plans include these categories and identify potential sources. Further research must focus on investigating whether the suspected impacts are a matter of concern. In this sense, we have suggested research questions to address the knowledge gaps and have a better understanding of the impacts and distribution of the new plastic forms.
\end{abstract}

(c) 2020 Elsevier B.V. All rights reserved.

\footnotetext{
* Corresponding author at: Universidad San Ignacio de Loyola, Faculty of Engineering, Av. la Fontana 501, La Molina, Lima, Peru.

E-mail addresses: gabriel.delatorre@usil.pe (G.E. De-la-Torre), diana.dioses@usil.pe (D.C. Dioses-Salinas), ivan.pizarro.co@gmail.com (C.I. Pizarro-Ortega), Isantillan@usil.edu.pe (L. Santillán).
} 


\section{Contents}

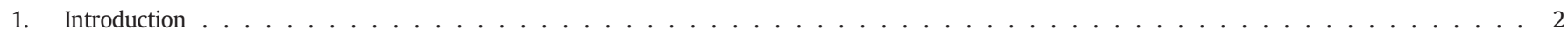

2. Methods... . . . . . . . . . . . . . . . . . . . . . . . . . . . . . . . . . . . . . 2

3. Plastiglomerates . . . . . . . . . . . . . . . . . . . . . . . . . . . . . . . . . . . . . 2

4. Pyroplastic . . . . . . . . . . . . . . . . . . . . . . . . . . . . . . . . . . . . 4

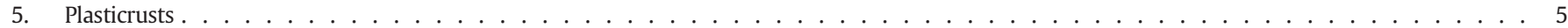

6. Anthropoquinas. . . . . . . . . . . . . . . . . . . . . . . . . . . . . . . . . . . . . 5

7. Conclusions and future perspectives. . . . . . . . . . . . . . . . . . . . . . . . . . . . . . . . . . . . . . . . 6

Declaration of competing interest ... . . . . . . . . . . . . . . . . . . . . . . . . . . . . . . . 6

Acknowledgments . . . . . . . . . . . . . . . . . . . . . . . . . . . . . . . . . . . . . . . . . . . 6

References. . . . . . . . . . . . . . . . . . . . . . . . . . . . . . . . . . . . . 7

\section{Introduction}

Since first manufactured in the beginnings of the XX century, plastic has become a material of widespread use due to its versatility, resistance, low-cost production, and lightweight (Verla et al., 2019). Nonetheless, the poor management on the post-consumer stage has made plastic a major environmental concern as a pollutant with a ubiquitous presence on the environment (Corcoran et al., 2018), found even in remote areas such as protected natural reserves, agroecosystems, glaciers, and arctic deep-sea sediments (Ambrosini et al., 2019; Bergmann et al., 2017; Dioses-Salinas et al., 2020). The long persistence and ubiquitous presence of plastic in environmental sediment samples have made researchers consider it as an indicator of the Anthropocene, which is a proposed epoch started in 1950 characterized by the alteration of natural processes by human activity and that has anthropogenic materials found in terrestrial and aquatic sediments as one of its indicative signatures (Waters et al., 2016). Effects on the biota and the environmental matrix (e.g. sediment, soil, water) quality and properties due to plastic debris pollution have been reported by several authors, especially on the marine environment (Qi et al., 2020; Verla et al., 2019).

For many years, the inputs of plastics from land into the ocean (Jambeck et al., 2015), their transportation in surface waters and cross convergence zones (Law et al., 2010) and vertical flux due to biofouling and subsequent increase in density (Hale et al., 2020) have been researched. Windsor et al. (2019) described the plastic fluxes among terrestrial, freshwater, cryospheric, atmospheric, and marine compartments. These models lack biotic elements, despite being known that plastic debris of various sizes is ingested by biota and humans (Setälä et al., 2018; Zhang et al., 2020). Recently, the concept of cycling was introduced to plastic pollution (Lecher, 2018). Like the biogeochemical cycles, the plastic cycle proposed by Bank and Hansson (2019) is defined as "the continuous and complex movement of plastic materials between different abiotic and biotic ecosystem compartments, including humans".

Recently, some authors have reported the presence of new plastic formations that may be the result of the interaction of plastic debris with other debris, anthropogenic processes, and elements of the environment (e.g. wood, waste burning, waves, sand, sediments, and organic materials) (Corcoran et al., 2014; Fernandino et al., 2020; Gestoso et al., 2019; Turner et al., 2019). Some of these new plastic forms or composites may no longer belong to one of the specific classifications defined by Hartmann et al. (2019). The new plastic formations have been reported mainly in coastal areas, in some cases from several countries, which is indicative of their global widespread distribution. They exhibit different physicochemical characteristics than their original plastic material, for example in terms of resistance to chemical, weathering, and mechanical abrasion or density (Corcoran et al., 2014). These changes may result in different effects and fate on the environment that need to be addressed. In addition, considerations on decontamination plans of these new pollutants may have to be taken, as the mixture of synthetic and organic components make the separation impractical and potentially impossible without affecting the ecosystem (Corcoran et al., 2014).

Due to their different characteristics, these new plastic formations cannot be considered to have the same behavior and impact than common plastic debris. Therefore, they emerge as a new challenge for the plastic pollution crisis. Moreover, there is a need for further studies and information analysis of the formation, transport mechanism, occurrence, and environmental effect of these new plastic forms to understand its ecological significance (Fernandino et al., 2020; Gestoso et al., 2019). Here, we focused on the current understanding of the new plastic formations reported in the literature. First, we summarized the definitions of the new plastic formations, namely plastiglomerate, pyroplastic, plasticrust and anthropoquina, and the available reports. Then, we analyzed and discussed the potential fate and impacts on the environment of each plastic formation based on their physical-chemical characteristics. We aim to present the new types of plastic pollution as a novel line of research in anthropogenic pollution and to provide guidance across the various knowledge gaps regarding their environmental impact.

\section{Methods}

A literature search was conducted in order to retrieve articles investigating new forms of marine plastic pollution. The keywords "plastiglomerate", "pyroplastic", "plasticrust" or "anthropoquina" were used to retrieve articles reporting these plastic-associated contaminants from the Scopus (https://www.scopus.com/), ScienceDirect (https://www.sciencedirect.com/), and Google Scholar (https://scholar. google.com/) databases. The references of the retrieved articles were also checked. These four terms were selected for describing new types of marine plastic pollution that are still poorly researched but apparently widespread. Based on their characteristics reported in the literature, their fate and potential effects on the environment were discussed for each of the novel plastic formations.

\section{Plastiglomerates}

In 2014, plastiglomerates were first described as an anthropogenic multi-composite matrix consisting of melted plastic, beach sediment or sand, basaltic lava debris and pieces of organic material (Corcoran et al., 2014) (Fig. 1a). These anthropogenic formations were reported for the first time in Kamilo Beach, Hawaii, and have been later observed in other parts of the world, including Indonesia, USA, Portugal, and Canada (Corcoran et al., 2018; Corcoran and Jazvac, 2020), although further physical-chemical characterization is required to understand their composition. Plastiglomerates are commonly referred to as a new type of rock. However, they are not officially defined as that, since rocks form naturally while plastiglomerates are the result of anthropogenic processes and materials (Corcoran and Jazvac, 2020). Like natural rocks, vesicles, and amygdules of plastic are commonly seen in 


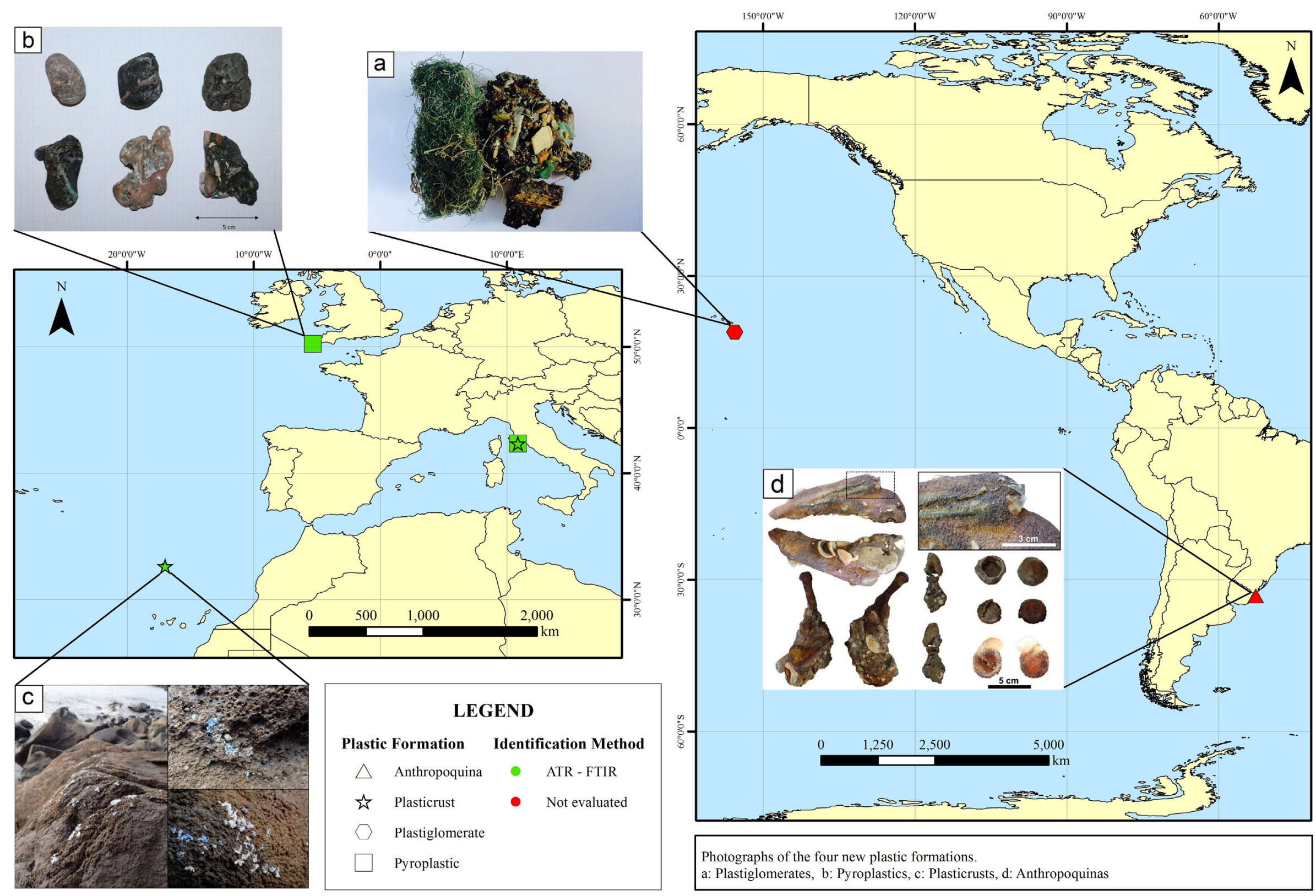

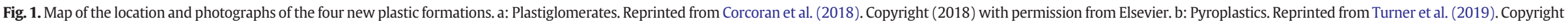

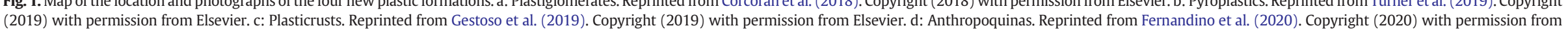
Elsevier. 
plastiglomerates (Corcoran and Jazvac, 2020). Corcoran et al. (2014) reported two types of plastiglomerates, the in situ types in which molten plastic adhered to rock surfaces, and a clastic-like indurated agglutination of basalt, shells and wood debris in a plastic matrix (Corcoran et al., 2014). The formation of plastiglomerates mainly derives from the burning of plastic material during, for instance, campfires or illegal waste burning. Evidence from fieldwork in Peru shows the remains of illegal waste burning sites (Fig. 2), where plastiglomerates could potentially be forming.

The intrusion of rocks and sediments increases the overall density of the plastic formation. Thus, plastiglomerates are not likely to travel by wind or ocean currents but to be buried in the sediment and, ultimately, become part of the rock record (Corcoran et al., 2014, 2018; Corcoran and Jazvac, 2020). After many years, technofossils (the remains of the technosphere preserved in the geological record) are expected to form (Zalasiewicz et al., 2014). Accordingly, the technosphere is the broadly distributed technological systems that modern societies are based on (Haff, 2012). Technological items (e.g., electronics) are mostly mentioned when referring to technofossils, although any item manufactured by humans at any scale has the potential to become that (Dibley, 2018). In this sense, plastiglomerates are not likely to enter the plastic cycle proposed by Bank and Hansson (2019). The fate of several plastics may be in the geological record, which is many times overlooked.

\section{Pyroplastic}

Pyroplastics, a subtype of clastic plastiglomerates, was recently described by Turner et al. (2019) as "an amorphous matrix that appears to be formed by the burning or melting of plastic and that is usually characterized by a single, neutral color (black-charcoal-grey, offwhite or brown), with occasional hues of green, blue, pink or yellow, and is accompanied by cracks and fractures, pits and cavities" (Fig. 1b). Unlike clastic plastiglomerates described previously (Corcoran et al., 2014), pyroplastics are positively buoyant in seawater, lack vesicles, and have smooth surfaces due to weathering conditions (Turner et al., 2019). Open campfires and plastic waste burning in beaches are the main sources of pyroplastics. Pyroplastics are sampled manually and through observation on the shoreline and rocky outcrops. In some cases, their identification is difficult due to their rock-like appearance (Turner et al., 2019).

Pyroplastics were first reported on beaches from England, Scotland, Ireland, Spain, and Canada (Turner et al., 2019). However, the morphology and chemical composition of only a subsample of 165 pyroplastics in Whitsand Bay (England) were measured. The mass ranged from 0.097 to $274 \mathrm{~g}$ and a median of $0.358 \mathrm{~g}$, while the aspect ratio (primary diameter divided by secondary diameter) ranged from 0.0422 to $7.50 \mathrm{~mm}$. Further analysis with Fourier transformed infrared (FTIR) spectroscopy revealed that pyroplastics from Whitsand Bay consisted of either polyethylene (PE) or polypropylene (PP) or both (Table 1) (Turner et al., 2019). Recently, in a coastal survey conducted by Ehlers and Ellrich (2020), a single pyroplastic was reported on Giglio island (Tyrrhenian Sea). The item from Giglio island was similar to those from Whitsand Bay in terms of morphology, but FTIR analysis determined polyethylene terephthalate (PET) as its polymer type. Determining the chemical composition of the pyroplastics using analytical techniques is necessary to avoid plastic-looking material to be regarded as such and helpful to understand the source of plastic pollution (e.g., PET is commonly found in plastic bottles).

We suggest that the buoyancy and durability of the pyroplastics could turn them into vectors of alien invasive species (AIS). Dispersal of marine invertebrates colonizing artificial substrata (mainly plastic waste) for long distances has been evidenced in various studies (Gracia and Rangel-Buitrago, 2020; Rech et al., 2018a, 2018b). Importantly, some in vitro studies suggest that bryozoan and ascidian species may prefer plastic surfaces for settlement over other artificial substrata (Chase et al., 2016; Li et al., 2016; Pinochet et al., 2020). Turner et al. (2019) found calcareous deposits of the polychaete worm Spirobranchus triqueter and apparent bryozoan Electra pilosa on the surfaces of some pyroplastics. This is an indicator that some pyroplastics were at some point submerged in coastal waters enough time for benthic macroinvertebrates to start colonizing them. Thus, being suitable for the dispersal of AIS upon reaching oceanic surface currents.

Similarly, pyroplastics, as other long-live floating plastic debris, could potentially be reservoirs and vectors of microbial communities including pathogens, thus having a role on the spread of microbial diseases for wildlife and humans. Due to their properties, plastics can create a habitat for various microbial pathogens such as algae, protists, viruses, fungi, and bacteria (Mammo et al., 2020). The biofilms present on the surface of plastic debris may protect the pathogens from mechanical damage, shear caused by water, predators, and stimulate bacterial growth due to the more availability of nutrients and metabolites (Tuson and Weibel, 2013). Therefore, increasing the survival rate of the pathogens and their threat to the human population and wildlife. Moreover, colonized pyroplastics could encounter effluents contaminated with antibiotics, resulting in the acquisition of antibiotic resistance

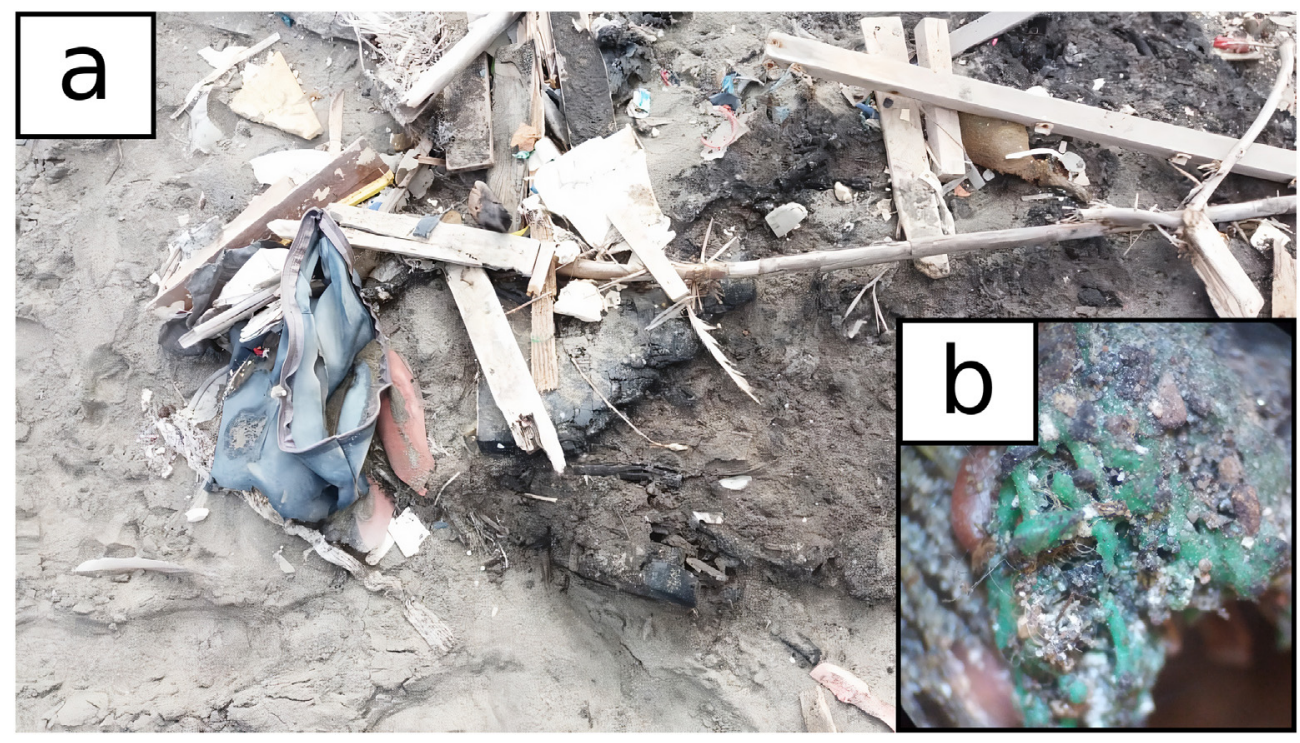

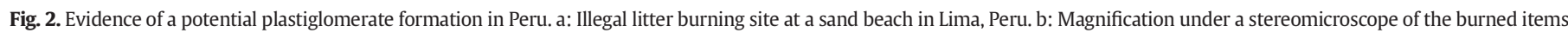
shows a melted and wood matrix with sand grains and fibers, possibly microplastics. 
Table 1

Synthetic polymers identified in the new plastic formations. ATR-FTIR: Attenuated total reflectance Fourier transformed infrared spectroscopy.

\begin{tabular}{|c|c|c|c|c|}
\hline Type of plastic & Technique & Polymer & Chemical structure & Reference \\
\hline Plastiglomerate & Not evaluated & - & - & (Corcoran et al., 2014) \\
\hline Anthropoquina & Not evaluated & - & - & (Fernandino et al., 2020) \\
\hline Pyroplastic & ATR-FTIR & Polypropylene (PP) & & (Turner et al., 2019) \\
\hline Pyroplastic & ATR-FTIR & Polyethylene terephthalate (PET) & & (Ehlers and Ellrich, 2020) \\
\hline Pyroplastic & ATR-FTIR & Polyethylene (PE) & & (Turner et al., 2019) \\
\hline Plasticrust & ATR-FTIR & Polyethylene (PE) & & (Ehlers and Ellrich, 2020) \\
\hline Plasticrust & ATR-FTIR & Polyethylene (PE) & & (Gestoso et al., 2019) \\
\hline
\end{tabular}

genes (ARGs) (Parthasarathy et al., 2019). The dissemination and migration of ARGs in plastic debris pose a higher risk to the environment and human health (Guo et al., 2020; Stange and Tiehm, 2020).

Weathering induce the release of chemical additives from plastic materials that can cause toxic effects in marine biota (Gandara e Silva et al., 2016; Teuten et al., 2009). Brominated flame retardants are among the most profound plastic additives in the industry and are known for their detrimental effects on biota. For example, hexabromocyclodecanes (HBCDs) and 1,2-dibromo-4-(1,2-dibromoethyl)-cyclohexane (TBECH) can biomagnify along the marine food web (Ruan et al., 2018) and cause reproductive and adverse behavioral effects in biota (Marvin et al., 2011). Other plastic-associated additives, like bisphenol A (BPA) are well known for their endocrine-disrupting effects (Rubin, 2011). Moreover, styrene oligomers (SOs) may leach from weathered PS plastics (De-la-Torre et al., 2020; Kwon et al., 2015; Saido et al., 2014), although these chemicals were first identified in beach sand recently and their possible effects remain unknown. Chemical leaching is an important subject for pyroplastics due to the environmental weathering processes they undergo. Marine biota attached to weathered plastics may perceive significant exposure to these contaminants, as reported in previous research studies (Jang et al., 2016). Hence, during their voyage, pyroplastics may serve as a vector for toxic chemicals, pathogens, and potentially AIS.

\section{Plasticrusts}

The term plasticrust was first coined by Gestoso et al. (2019) and describes plastic pieces encrusted in the texture of intertidal rocks that may persist over time (Fig. 1c). The formation of plasticrusts is suggested to be caused by the coastal wave-induced crash of larger plastic items against rock outcrops. Factors inducing the spread of plasticrusts are levels of plastic pollution nearshore, tidal amplitude, and wave exposure (Ehlers and Ellrich, 2020). According to Corcoran and Jazvac (2020), plasticrusts are now included as a type of in situ plastiglomerate. Sampling techniques are simple, encompassing the use of quadrants on the affected intertidal rocks. Then, the samples are collected by scraping the surface of the encrusted area (Gestoso et al., 2019).

First observations made on the island of Madeira (NE Atlantic) showed plasticrust pieces identified as PE of $0.77 \pm 0.10 \mathrm{~mm}$ in thickness and covering $9.46 \pm 1.77 \%$ in the affected areas (Gestoso et al., 2019). Later research reported plasticrust formations in Giglio island (Ehlers and Ellrich, 2020). Similar to the ones reported by Gestoso et al. (2019), all of the plasticrusts were chemically identified as PE. However, a low cover of $0.02 \pm 0.01 \%\left(0.46 \pm 0.08 \mathrm{~mm}^{2}\right.$ in area) was observed. Plasticrust thickness ranged from 0.5 to $0.7 \mathrm{~mm}$ and the abundance was $3.25 \pm 1.65$ plasticrusts $/ \mathrm{dm}^{2}$ (Ehlers and Ellrich, 2020).

The presence of plasticrusts in intertidal rocky formations may affect common marine invertebrates and grazers. In Madeira, Gestoso et al. (2019) observed the presence of gastropod Tectarius striatus resting on plasticrusts and their surroundings. These organisms may be subject to plastic debris ingestion as in vitro studies indicated that periwinkles fed from algae contaminated with adherent microplastics (Gutow et al., 2016). However, in Giglio marine gastropods were not found within the reach of plasticrusts (Ehlers and Ellrich, 2020). Instead, marbled rock crabs (Pachygrapsus marmoratus) were identified at the same elevation as the plasticrusts area. Thus, plasticrusts are possibly making their way into the marine food web. Regarding echinoderms, sea urchin grazing activity on a plastic surface may bioerode it into tens of smaller plastic particles (ranging from 118 to $15,797 \mu \mathrm{m}$ ) after some days (Porter et al., 2019). It is unknown whether grazing activity by other benthic marine invertebrates could cause the same effects. Evidence suggests that the interaction of local grazers with plasticrusts could lead to the formation of microplastics $(<5 \mathrm{~mm})$. Microplastics transfer from prey to predator and escalate to higher trophic levels (De-laTorre, 2020; Nelms et al., 2018), ultimately impacting on top predators, such as marine mammals and seabirds. Upon entering the food web, the plasticrust-derived microplastics enter the plastic cycle (Bank and Hansson, 2019). However, it is unknown whether plasticrusts serve as a significant source of microplastics.

\section{Anthropoquinas}

More recently, the term anthropoquinas was coined by Fernandino et al. (2020) describing sedimentary rocks that contain objects of anthropogenic source, including plastic, and other organic material (Fig. 1d). Anthropogenic materials cemented in sedimentary beach rocks were reported in previous studies (Arrieta et al., 2011; Irabien et al., 2015), composed mainly of brick fragments, glass, plastic, and slags. These anthropogenic artifacts, namely technofossils (Zalasiewicz et al., 2014), are likely to follow the same fate as plastiglomerates and become part of the geological cycle. Zalasiewicz et al. (2011) argue that the environmental changes by anthropogenic activities are enough to formalize a chronostratigraphic definition of the Anthropocene epoch. However, since the concept of the Anthropogenic epoch is based on the present and future, it does not fulfill formal requirements by the International Commission on Stratigraphy (Finney and Edwards, 2016). This topic remains under debate by the scientific community. Under this context, formally defining anthropoquinas is important for this line of research.

In the study by Fernandino et al. (2020), six samples were collected opportunistically from beaches in the state of Rio Grande do Sul, Brazil. Metal (ship's nail and other items), plastic, shells, and pebbles cemented with grained sand are among the materials found. Importantly, metal bottle caps and pearl earrings were found cemented with fine-grained sands. This indicates how versatile the genesis of anthropoquinas can be. Although previous studies reported similar objects cemented in sedimentary rocks, this is the first study giving especial detail to the anthropogenic items and giving a name to this geo-anthropogenic phenomenon. 


\section{Conclusions and future perspectives}

Plastic pollution is widespread worldwide. The interactions of plastic wastes with environmental and anthropogenic conditions give rise to new forms of pollution (Fig. 3). Here, a literature review was conducted, and the possible environmental impacts were identified with respect to four newly defined plastic formations in the Anthropocene: Plastiglomerates, pyroplastics, plasticrusts, and anthropoquinas. The possible impacts vary due to their characteristics and their interaction with the natural conditions. Plastiglomerates and pyroplastics may release toxic chemicals and plastic-associated contaminants into the environment due to their exposure to high temperatures. In addition, we suspect that pyroplastics can become vectors for AIS and microbial pathogens as they are positively buoyant and persistent in the marine environment. Plasticrusts can affect marine biota due to the possibility of ingesting plastics, for example, echinoderms, when they graze on plastic surfaces, are capable of bioerode in many smaller plastic particles, namely microplastics, and possibly making its way into the marine food chain. Anthropoquinas, on the other hand, are a demonstration of how various types of anthropogenic waste enter the geological cycle.

The available literature on sampling techniques on these new plastic formations is very limited. Therefore, more research is required in the process of extracting or collecting the samples, including their isolation and conservation. As a standard protocol has not been established, the results of the few studies are difficult to compare, accordingly establishing minimum conditions for their respective sampling processes is necessary. Samples extracted from the environment need to be analyzed by chemical means, like FTIR or Raman spectroscopy, and the polymer types must be reported. Likewise, a better understanding of their interaction with environmental conditions is essential to assess the real risk that these new types of contamination can represent. This short review shows a bigger picture regarding the fate and potential environmental impacts of the new plastic formations. Further worldwide occurrence of these new plastic formations must be addressed to avoid underestimating plastic pollution in the marine environment. In agreement with Gestoso et al. (2019), it is important to include these new plastic litter categories in monitoring guidelines and action plans.

We suggest that the new plastic formations may be impacting the marine environment in various ways based on their characteristics. Since these terms were coined very recently, studies are limited to reporting the occurrence rather than assessing their impacts and only a few evaluated the chemical composition of the suspected plastic formations. To determine whether these contaminants are globally widespread as suspected, significant efforts must be devoted to investigating and report the occurrence of the new plastic formations. Future research must also consider quantifying the environmental impacts, especially regarding the transport of AIS, transport of ARGs, plastic ingestion, and the release of plastic-associated contaminants. Hence, the following research questions need to be addressed:

Question 1: What are the standard procedures and considerations for sampling plastiglomerates, pyroplastics, plasticrusts, or anthropoquinas?

Question 2: What role do pyroplastics play in the transport of AIS and ARGs?

Question 3: Is plastic ingestion in marine invertebrates and rock dwellers associated with the presence of plasticrusts?

Question 4: Is the rate of toxic chemical release altered by the burning and weathering conditions plastiglomerates and pyroplastics undergo?

Question 5: What are the most and least important factors attributed to the formation of plastiglomerates, pyroplastics, plasticrusts, or anthropoquinas? What areas or landforms are most likely to host these novel plastic formations?

\section{Declaration of competing interest}

The authors declare that they have no known competing financial interests or personal relationships that could have appeared to influence the work reported in this paper.

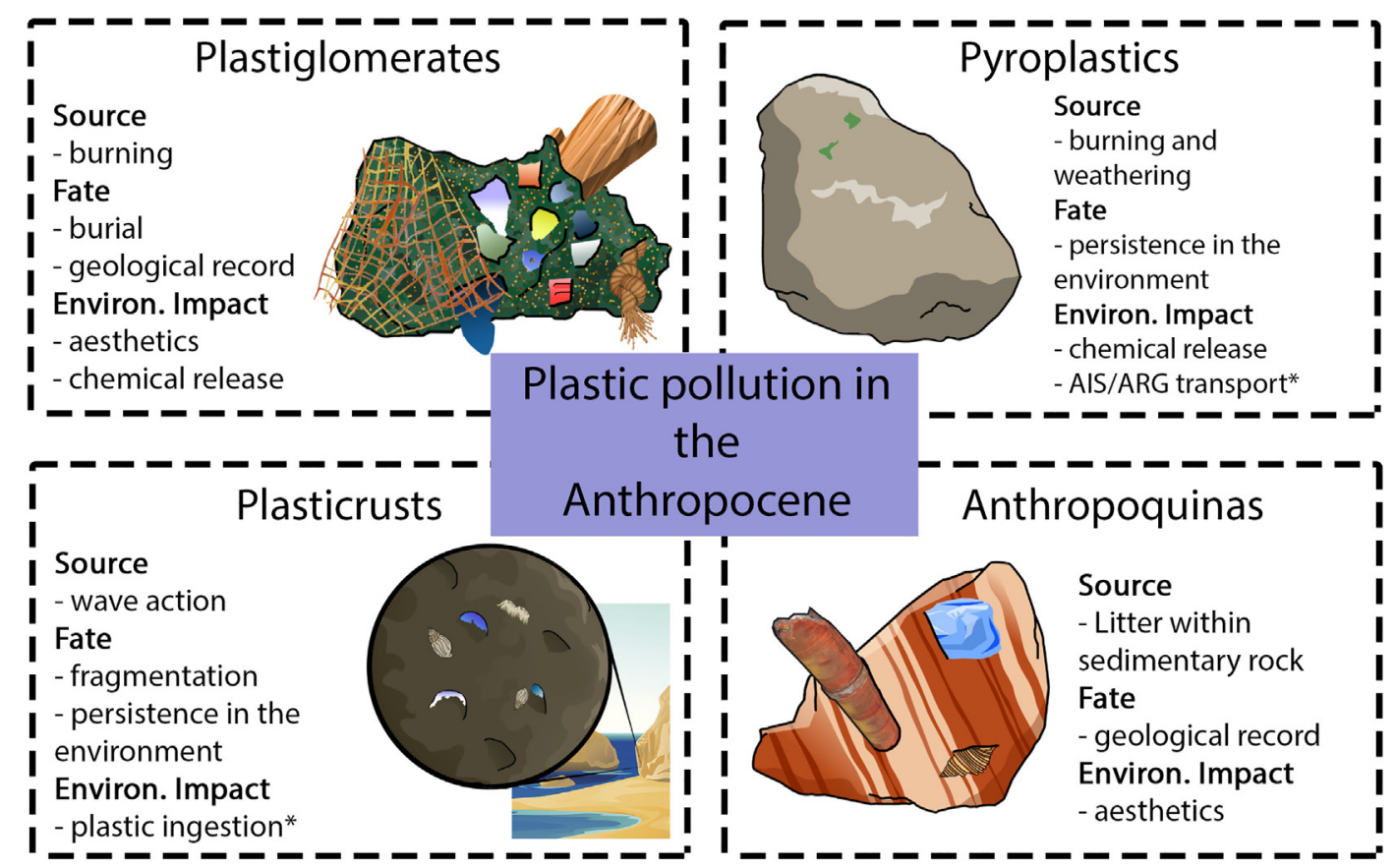

Fig. 3. Visual representation and main characteristics of the new plastic formations described in the literature. *: Suspected environmental impact. 


\section{Acknowledgments}

The authors are thankful to the five peer-reviewers for their comments and suggestions which added enormously to the revised paper. This research was funded by Universidad San Ignacio de Loyola.

\section{References}

Ambrosini, R., Azzoni, R.S., Pittino, F., Diolaiuti, G., Franzetti, A., Parolini, M., 2019. First evidence of microplastic contamination in the supraglacial debris of an alpine glacier. Environ. Pollut. 253, 297-301. https://doi.org/10.1016/j.envpol.2019.07.005.

Arrieta, N., Goienaga, N., Martínez-Arkarazo, I., Murelaga, X., Baceta, J.I., Sarmiento, A Madariaga, J.M., 2011. Beachrock formation in temperate coastlines: examples in sand-gravel beaches adjacent to the Nerbioi-Ibaizabal Estuary (Bilbao, bay of Biscay, north of Spain). Spectrochimica Acta - Part A: Molecular and Biomolecular Spectroscopy. Elsevier, pp. 55-65 https://doi.org/10.1016/j.saa.2011.01.031.

Bank, M.S., Hansson, S.V., 2019. The plastic cycle: a novel and holistic paradigm for the anthropocene. Environ. Sci. Technol. 53, 7177-7179. https://doi.org/10.1021/acs. est.9b02942.

Bergmann, M., Wirzberger, V., Krumpen, T., Lorenz, C., Primpke, S., Tekman, M.B., Gerdts, G., 2017. High quantities of microplastic in Arctic deep-sea sediments from the HAUSGARTEN observatory. Environ. Sci. Technol. 51, 11000-11010. https://doi.org/ 10.1021/acs.est.7b03331.

Chase, A.L., Dijkstra, J.A., Harris, L.G., 2016. The influence of substrate material on ascidian larval settlement. Mar. Pollut. Bull. 106, 35-42. https://doi.org/10.1016/j. marpolbul.2016.03.049.

Corcoran, P.L., Jazvac, K., 2020. The consequence that is plastiglomerate. Nat. Rev. Earth Environ. 1, 6-7. https://doi.org/10.1038/s43017-019-0010-9.

Corcoran, P.L., Moore, C.J., Jazvac, K., 2014. An anthropogenic marker horizon in the future rock record. GSA Today (2), 4, 4-8 https://doi.org/10.1130/GSAT-G198A.1.

Corcoran, P.L., Jazvac, K., Ballent, A., 2018. Plastics and the anthropocene. Encyclopedia of the Anthropocene. Elsevier, pp. 163-170 https://doi.org/10.1016/B978-0-12-8096659.10000-X.

De-la-Torre, G.E., 2020. Microplastics: an emerging threat to food security and human health. J. Food Sci. Technol. 57, 1601-1608. https://doi.org/10.1007/s13197-01904138-1.

De-la-Torre, G.E., Dioses-Salinas, D.C., Castro, J.M., Antay, R., Fernández, N.Y., EspinozaMorriberón, D., Saldaña-Serrano, M., 2020. Abundance and distribution of microplastics on sandy beaches of Lima, Peru. Mar. Pollut. Bull. 151, 110877. https://doi.org/10.1016/ j.marpolbul.2019.110877.

Dibley, B., 2018. The technofossil: a memento mori. J. Contemp. Archaeol. 5, 44-52. https://doi.org/10.1558/jca.33380

Dioses-Salinas, D.C., Pizarro-Ortega, C.I., De-la-Torre, G.E., 2020. A methodological approach of the current literature on microplastic contamination in terrestrial environments: current knowledge and baseline considerations. Sci. Total Environ. 730, 139164. https://doi.org/10.1016/j.scitotenv.2020.139164.

Ehlers, S.M., Ellrich, J.A., 2020. First record of 'plasticrusts' and 'pyroplastic' from the Mediterranean Sea. Mar. Pollut. Bull. 151, 110845. https://doi.org/10.1016/j. marpolbul.2019.110845.

Fernandino, G., Elliff, C.I., Francischini, H., Dentzien-Dias, P., 2020. Anthropoquinas: first description of plastics and other man-made materials in recently formed coastal sedimentary rocks in the southern hemisphere. Mar. Pollut. Bull. 154, 111044. https:// doi.org/10.1016/j.marpolbul.2020.111044.

Finney, S.C., Edwards, L.E., 2016. The “Anthropocene” epoch: scientific decision or political statement? GSA Today 26, 4-10. https://doi.org/10.1130/GSATG270A.1.

Gandara e Silva, P.P., Nobre, C.R., Resaffe, P., Pereira, C.D.S., Gusmão, F., 2016. Leachate from microplastics impairs larval development in brown mussels. Water Res. 106, 364-370. https://doi.org/10.1016/j.watres.2016.10.016.

Gestoso, I., Cacabelos, E., Ramalhosa, P., Canning-Clode, J., 2019. Plasticrusts: a new potential threat in the Anthropocene's rocky shores. Sci. Total Environ. 687, 413-415. https://doi.org/10.1016/j.scitotenv.2019.06.123.

Gracia, A.A., Rangel-Buitrago, N., 2020. The invasive species Perna viridis (Linnaeus, 1758 - Bivalvia: Mytilidae) on artificial substrates: a baseline assessment for the Colombian Caribbean Sea. Mar. Pollut. Bull. 152, 110926. https://doi.org/ 10.1016/j.marpolbul.2020.110926.

Guo, X. pan, Sun, X. li, Chen, Y. ru, Hou, L., Liu, M., Yang, Y., 2020. Antibiotic resistance genes in biofilms on plastic wastes in an estuarine environment. Sci. Total Environ. 745, 140916. https://doi.org/10.1016/j.scitotenv.2020.140916.

Gutow, L., Eckerlebe, A., Giménez, L., Saborowski, R., 2016. Experimental evaluation of seaweeds as a vector for microplastics into marine food webs. Environ. Sci. Technol. 50, 915-923. https://doi.org/10.1021/acs.est.5b02431.

Haff, P.K., 2012. Technology and human purpose: the problem of solids transport on the Earth's surface. Earth Syst. Dyn. 3, 149-156. https://doi.org/10.5194/esd-3-149-2012.

Hale, R.C., Seeley, M.E., La Guardia, M.J., Mai, L., Zeng, E.Y., 2020. A global perspective on microplastics. J. Geophys. Res. Ocean 125, e14719. https://doi.org/10.1029/ 2018JC014719.

Hartmann, N.B., Hüffer, T., Thompson, R.C., Hassellöv, M., Verschoor, A., Daugaard, A.E. Rist, S., Karlsson, T., Brennholt, N., Cole, M., Herrling, M.P., Hess, M.C., Ivleva, N.P., Lusher, A.L., Wagner, M., 2019. Are we speaking the same language? Recommendations for a definition and categorization framework for plastic debris. Environ. Sci. Technol. 53, 1039-1047. https://doi.org/10.1021/acs.est.8b05297.

Irabien, M.J., García-Artola, A., Cearreta, A., Leorri, E., 2015. Chemostratigraphic and lithostratigraphic signatures of the Anthropocene in estuarine areas from the eastern
Cantabrian coast (N. Spain). Quat. Int. 364, 196-205. https://doi.org/10.1016/j. quaint.2014.08.056.

Jambeck, J.R., Geyer, R., Wilcox, C., Siegler, T.R., Perryman, M., Andrady, A., Narayan, R., Law, K.L., 2015. Plastic waste inputs from land into the ocean. Science (80-. ). 347, 768-771. https://doi.org/10.1126/science.1260352.

Jang, M., Shim, W.J., Han, G.M., Rani, M., Song, Y.K., Hong, S.H., 2016. Styrofoam debris as a source of hazardous additives for marine organisms. Environ. Sci. Technol. 50, 4951-4960. https://doi.org/10.1021/acs.est.5b05485.

Kwon, B.G., Koizumi, K., Chung, S.Y., Kodera, Y., Kim, J.O., Saido, K., 2015. Global styrene oligomers monitoring as new chemical contamination from polystyrene plastic marine pollution. J. Hazard. Mater. 300, 359-367. https://doi.org/10.1016/j.jhazmat.2015.07.039.

Law, K.L., Morét-Ferguson, S., Maximenko, N.A., Proskurowski, G., Peacock, E.E., Hafner, J., Reddy, C.M., 2010. Plastic accumulation in the North Atlantic subtropical gyre. Science (80-. ). 329, 1185-1188. https://doi.org/10.1126/science.1192321.

Lecher, A.L., 2018. Piecing together the plastic cycle. Nat. Geosci. 11, 153. https://doi.org/ 10.1038/s41561-018-0077-9.

Li, H.X., Orihuela, B., Zhu, M., Rittschof, D., 2016. Recyclable plastics as substrata for settlement and growth of bryozoans Bugula neritina and barnacles Amphibalanus amphitrite. Environ. Pollut. 218, 973-980. https://doi.org/10.1016/j.envpol.2016.08.047.

Mammo, F.K., Amoah, I.D., Gani, K.M., Pillay, L., Ratha, S.K., Bux, F., Kumari, S., 2020. Microplastics in the environment: interactions with microbes and chemical contaminants. Sci. Total Environ. 743, 140518. https://doi.org/10.1016/j.scitotenv.2020.140518.

Marvin, C.H., Tomy, G.T., Armitage, J.M., Arnot, J.A., McCarty, L., Covaci, A., Palace, V., 2011. Hexabromocyclododecane: current understanding of chemistry, environmental fate and toxicology and implications for global management. Environ. Sci. Technol. 45, 8613-8623. https://doi.org/10.1021/es201548c.

Nelms, S.E., Galloway, T.S., Godley, B.J., Jarvis, D.S., Lindeque, P.K., 2018. Investigating microplastic trophic transfer in marine top predators. Environ. Pollut. 238, 999-1007. https://doi.org/10.1016/j.envpol.2018.02.016.

Parthasarathy, A., Tyler, A.C., Hoffman, M.J., Savka, M.A., Hudson, A.O., 2019. Is plastic pollution in aquatic and terrestrial environments a driver for the transmission of pathogens and the evolution of antibiotic resistance? Environ. Sci. Technol. 53, 1744-1745. https://doi.org/10.1021/acs.est.8b07287.

Pinochet, J., Urbina, M.A., Lagos, M.E., 2020. Marine invertebrate larvae love plastics: habitat selection and settlement on artificial substrates. Environ. Pollut. 257, 113571. https://doi.org/10.1016/j.envpol.2019.113571.

Porter, A., Smith, K.E., Lewis, C., 2019. The sea urchin Paracentrotus lividus as a bioeroder of plastic. Sci. Total Environ. 693, 133621. https://doi.org/10.1016/j.scitotenv.2019.133621.

Qi, R., Jones, D.L., Li, Z., Liu, Q., Yan, C., 2020. Behavior of microplastics and plastic film residues in the soil environment: a critical review. Sci. Total Environ. https://doi.org/ 10.1016/j.scitotenv.2019.134722.

Rech, S., Salmina, S., Borrell Pichs, Y.J., García-Vazquez, E., 2018a. Dispersal of alien invasive species on anthropogenic litter from European mariculture areas. Mar. Pollut. Bull. 131, 10-16. https://doi.org/10.1016/j.marpolbul.2018.03.038.

Rech, S., Thiel, M., Borrell Pichs, Y.J., García-Vazquez, E., 2018b. Travelling light: fouling biota on macroplastics arriving on beaches of remote Rapa Nui (Easter Island) in the South Pacific Subtropical Gyre. Mar. Pollut. Bull. 137, 119-128. https://doi.org/ 10.1016/j.marpolbul.2018.10.015.

Ruan, Y., Zhang, X., Oiu, J.W., Leung, K.M.Y., Lam, J.C.W., Lam, P.K.S., 2018. Stereoisomerspecific trophodynamics of the chiral brominated flame retardants HBCD and TBECH in a marine food web, with implications for human exposure. Environ. Sci. Technol. 52, 8183-8193. https://doi.org/10.1021/acs.est.8b02206.

Rubin, B.S., 2011. Bisphenol A: an endocrine disruptor with widespread exposure and multiple effects. J. Steroid Biochem. Mol. Biol. 127, 27-34. https://doi.org/10.1016/j. jsbmb.2011.05.002.

Saido, K., Koizumi, K., Sato, H., Ogawa, N., Kwon, B.G., Chung, S.Y., Kusui, T., Nishimura, M., Kodera, Y., 2014. New analytical method for the determination of styrene oligomers formed from polystyrene decomposition and its application at the coastlines of the North-West Pacific Ocean. Sci. Total Environ. 473-474, 490-495. https://doi.org/ 10.1016/j.scitotenv.2013.12.081.

Setälä, O., Lehtiniemi, M., Coppock, R., Cole, M., 2018. Microplastics in marine food webs. Microplastic Contamination in Aquatic Environments: An Emerging Matter of Environmental Urgency. Elsevier, pp. 339-363 https://doi.org/10.1016/B978-0-12813747-5.00011-4.

Stange, C., Tiehm, A., 2020. Occurrence of antibiotic resistance genes and microbial source tracking markers in the water of a karst spring in Germany. Sci. Total Environ. 742, 140529. https://doi.org/10.1016/j.scitotenv.2020.140529.

Teuten, E.L., Saquing, J.M., Knappe, D.R.U., Barlaz, M.A., Jonsson, S., Björn, A., Rowland, S.J., Thompson, R.C., Galloway, T.S., Yamashita, R., Ochi, D., Watanuki, Y., Moore, C., Viet, P.H., Tana, T.S., Prudente, M., Boonyatumanond, R., Zakaria, M.P., Akkhavong, K., Ogata, Y., Hirai, H., Iwasa, S., Mizukawa, K., Hagino, Y., Imamura, A., Saha, M., Takada, H., 2009. Transport and release of chemicals from plastics to the environment and to wildlife. Philos. Trans. R. Soc. B Biol. Sci 364, 2027-2045. https://doi.org/ 10.1098/rstb.2008.0284.

Turner, A., Wallerstein, C., Arnold, R., Webb, D., 2019. Marine pollution from pyroplastics. Sci. Total Environ. 694, 133610. https://doi.org/10.1016/j.scitotenv.2019.133610.

Tuson, H.H., Weibel, D.B., 2013. Bacteria-surface interactions. Soft Matter 9, 4368-4380. https://doi.org/10.1039/c3sm27705d.

Verla, A.W., Enyoh, C.E., Verla, E.N., Nwarnorh, K.O., 2019. Microplastic-toxic chemical interaction: a review study on quantified levels, mechanism and implication. SN Appl. Sci. 1, 1-30. https://doi.org/10.1007/s42452-019-1352-0.

Waters, C.N., Zalasiewicz, J., Summerhayes, C., Barnosky, A.D., Poirier, C., Ga uszka, A., Cearreta, A., Edgeworth, M., Ellis, E.C., Ellis, M., Jeandel, C., Leinfelder, R., McNeill, J.R., Richter, D.d., Steffen, W., Syvitski, J., Vidas, D., Wagreich, M., Williams, M., Zhisheng, A., Grinevald, J., Odada, E., Oreskes, N., Wolfe, A.P., 2016. The Anthropocene 
is functionally and stratigraphically distinct from the Holocene. Science (80-. )., 351 https://doi.org/10.1126/science.aad2622.

Windsor, F.M., Durance, I., Horton, A.A., Thompson, R.C., Tyler, C.R., Ormerod, S.J., 2019. A catchment-scale perspective of plastic pollution. Glob. Chang. Biol. 25, 1207-1221. https://doi.org/10.1111/gcb.14572.

Zalasiewicz, J., Williams, M., Fortey, R., Smith, A., Barry, T.L., Coe, A.L., Bown, P.R., Rawson, P.F., Gale, A., Gibbard, P., Gregory, F.J., Hounslow, M.W., Kerr, A.C., Pearson, P., Knox, R. Powell, J., Waters, C., Marshall, J., Oates, M., Stone, P., 2011. Stratigraphy of the
Anthropocene. Philos. Trans. R. Soc. A Math. Phys. Eng. Sci. 369, 1036-1055. https:// doi.org/10.1098/rsta.2010.0315.

Zalasiewicz, J., Williams, M., Waters, C.N., Barnosky, A.D., Haff, P., 2014. The technofossil record of humans. Anthropol. Rev. 1, 34-43. https://doi.org/ $10.1177 / 2053019613514953$.

Zhang, Q., Xu, E.G., Li, J., Chen, Q., Ma, L., Zeng, E.Y., Shi, H., 2020. A review of microplastics in table salt, drinking water, and air: direct human exposure. Environ. Sci. Technol. 54, 3740-3751. https://doi.org/10.1021/acs.est.9b04535. 